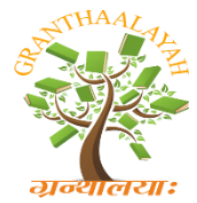

\author{
INTERNATIONAL JOURNAL OF RESEARCH \\ GRANTHAALAYAH \\ A knowledge Repository
}

Science

\title{
MOLLUSCAN BIODIVERSITY AND ITS SEASONAL FLUCTUATIONS IN TEEKAR TAAL, HARYANA, INDIA
}

\author{
Ravinder Kumar ${ }^{1}$, Maansi ${ }^{1}$, Meenu Wats ${ }^{* 1}$ \\ ${ }^{* 1}$ Post Graduate Department of Zoology D.A.V. College Sector-10 Chandigarh, Panjab \\ University, India
}

\begin{abstract}
Freshwater molluscs are the integral part of every aquatic ecosystem and help not only in the ecosystem's functioning but also enable the ecologists to judge the health of their abode. These shelled animals are used as the best biomonitoring tools worldwide. Gradually declining water quality of freshwater bodies owing to multiple factors, their biodiversity is also facing threat. Majority of the freshwater bodies near human vicinities are facing anthropogenic interventions, habitat destructions and overexploitation and the same is being reflected by the elimination of sensitive molluscan species and survival as well as abundance of other tolerant ones. The current study has been undertaken to understand the Malacofauna biodiversity in Morni hills, Panchkula, Haryana. During the study, total 359 gastropods both aquatic and land snails were collected. Premonsoon season witnessed greater molluscan abundance, 8.46 times, than post-monsoon. The molluscan biodiversity, 7 species, 7 Genera and 5 families, namely Filopaludina bengalensis, Melanoides tuberculata, Radix luteola, Gyraulus ladacensis, Indoplanorbis exustus, Ariophanta interrupta and Macrochlamys indica.Shannon-Weiner Index (H) and Simpson Diversity Index (D) for both seasons indicated higher species diversity during post monsoon season. Melanoides tuberculata was found to be dominant during pre-monsoon while Filopaludina bengalensis during post monsoon season.
\end{abstract}

Keywords: Gastropods; Teekar Taal; Malacofauna; Pre monsoon and Post monsoon.

Cite This Article: Ravinder Kumar, Maansi, and Meenu Wats. (2019). "MOLLUSCAN BIODIVERSITY AND ITS SEASONAL FLUCTUATIONS IN TEEKAR TAAL, HARYANA, INDIA." International Journal of Research - Granthaalayah, 7(1), 169-178. https://doi.org/10.29121/granthaalayah.v7.i1.2019.1045.

\section{Introduction}

The Molluscs are soft bodied animals, with or without external shell showing great diversity and antiquity. These animals were found throughout the world in wide range of habitats including marine, freshwater and terrestrial. Factors like temperature, nature and abundance of vegetation, nature of substrate and chemical compositions of water as well as substrate play vital role in their occurrence, distribution and density. These important part of every aquatic ecosystem, many 
species act as food sources to many animals as well as human beings (species like Filopaludina bengalensis, Pila globosa and Brotia costula). Other helps in nutrient cycle and are also used as bio indicator of their ecosystem's pollution, hence play a pivot role in ecological studies (Sharma et al., 2013; Kumar et al., 2018) of aquatic ecosystems.

The taxonomic study of molluscs started more than two centuries ago (Benson, 1832) in India and since then the taxonomic literature on Indian freshwater molluscs had been found scattered and scanty some of the worth mentioning ones are: Ray, 1951 (Coramendal coast of India); Ray, 1961 (South India); Agarwal, 1975a, b (Himachal Pradesh); Subba Rao \& Mitra, 1979 (Pune); Mitra and Day, 1992 (West Bengal); Subba Rao, 1993 (India); Subba Rao \& Mitra, 1995 (Western Himalaya); Surya Rao and Mitra, 1997, (Nanda Devi Biosphere Reserve); Sharma, 1997 (Southern Rajasthan); Patil, 2002 (Ereavikulam National Park); Surya Rao et al., 2002b (Ujjaini); Patil and Talmale, 2005 (Maharashtra); Sharma et al., 2005 (Western Uttar Pradesh); Roy and Gupta, 2010 (Barak River of Assam); Khade and Mane, 2012 (Ratnagiri, Maharashtra); Kumar and Vyas, 2012 (Narmada river); Biswas et al., 2015 (Kangra, Himachal Pradesh)

The present study is the first attempt to identify the malaco-diversity in Teekar Taal along with understanding their diversity and abundance fluctuations in different seasons.

\section{Methodology}

\section{Study Area}

Teekar Taal also known as Bhim Taal is a natural lake located in Morni hills of district Panchkula, Haryana (Figure 1) with width of $550 \mathrm{~m}$ and length $460 \mathrm{~m}$ also a perfect tourist place surrounded by lush green hillocks. The water is also used for various other purposes like irrigation and animal bathing.
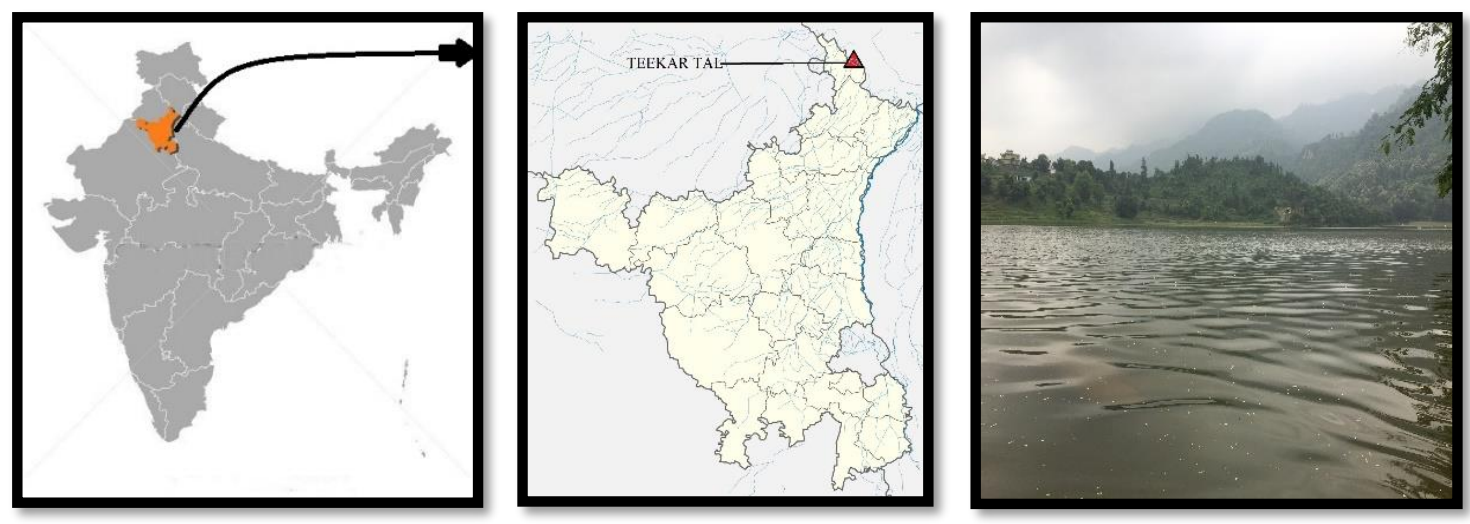

Figure 1: Location of Teekar Taal $30.6873^{\circ} \mathrm{N} ; 77.0877^{\circ} \mathrm{E}$

\section{Sampling}

Soil sampling, from littoral and sub littoral zone, was done during pre and post-monsoon seasons (2018) with the help of modified Dandy sampler. Shells were also hand-picked from the shoreline area too. The soil samples were brought to the laboratory, sieved through Standard Test Sieves of different mesh sizes (BSS 75mm, 44mm, 30mm, 10mm, and 4mm), shells were picked from sieves $(75 \mathrm{~mm}, 44 \mathrm{~mm}$ and $30 \mathrm{~mm})$. The soft tissues were preserved in $5 \%$ formalin and empty shells were 
cleaned using brushes and Stored after drying. The identification was done on the basis of morphological characters by following the keys given by Subbha Rao 1989; Ramakrishna and Dey 2005; Dey, 2007.

\section{Statistical Analysis}

To understand the species richness/diversity and abundance of molluscan fauna, in Teekar Taal during pre and post monsoon season following indices were used: -

1) Shannon-Weiner Index (Shannon-Weiner, 1949)

This Index is used to characterize species richness/diversity in a community. It is calculated by using formula, $\mathrm{H}=-\Sigma p_{i} \ln p_{i}$

$p_{i}=$ Proportion of individuals found of species $i^{\text {th }}$ in the sample.

2) Simpson's Diversity Index (Simpson, 1949)

This Index is a measure of diversity which takes into account the number of species present as well as the relative abundance of each species. It is calculated by using formula

$\mathrm{D}=1-\left[\frac{\sum n(n-1)}{N(N-1)}\right]$

$\mathrm{n}=$ Total number of individuals of particular species

$\mathrm{N}=$ Total number of individuals of all species

\section{Results and Discussion}

During the study, total of 359 specimens belonging to 7 species, 5 families and 7 genus of gastropods were collected (Table 1). Maximum numbers of specimens were collected during premonsoon while maximum variety during post-monsoon (Table 2).

Table 1: Classification of collected fauna from Teekar Taal during study period

\begin{tabular}{|c|c|c|c|c|c|c|}
\hline Phylum & Class & Habitat & Family & Genus & Species & form \\
\hline \multirow{8}{*}{$\begin{array}{l}\text { Mollusc } \\
\mathrm{a}\end{array}$} & \multirow{8}{*}{$\begin{array}{l}\text { Gastropod } \\
\text { a }\end{array}$} & \multirow{6}{*}{$\begin{array}{l}\text { Freshwate } \\
\mathrm{r}\end{array}$} & \multirow[t]{2}{*}{ Viviparidae } & \multirow[t]{2}{*}{ Filopaludina } & \multirow{2}{*}{$\begin{array}{l}\text { bengalensi } \\
s\end{array}$} & typica \\
\hline & & & & & & $\begin{array}{l}\text { mandiensi } \\
S\end{array}$ \\
\hline & & & Thiaridae & Melanoides & $\begin{array}{l}\text { tuberculat } \\
a\end{array}$ & \\
\hline & & & Lymnaeidae & Radix & luteola & typica \\
\hline & & & \multirow[t]{2}{*}{ Planorbidae } & Gyraulus & ladacensis & \\
\hline & & & & Indoplanorbis & exustus & \\
\hline & & \multirow[t]{2}{*}{ Terrestrial } & \multirow{2}{*}{$\begin{array}{l}\text { Ariophantida } \\
\text { e }\end{array}$} & Ariophanta & interrupta & \\
\hline & & & & $\begin{array}{l}\text { Macrochlamy } \\
S\end{array}$ & indica & \\
\hline
\end{tabular}

Table 2: Number of species collected during pre-monsoon and post monsoon season

\begin{tabular}{|l|l|l|l|l|}
\hline Molluscan Species & \multicolumn{2}{|l|}{ Pre monsoon } & \multicolumn{2}{l|}{ Post monsoon } \\
\hline Filopaludina bengalensis & + & 85 & + & 15 \\
\hline Melanoides tuberculata & + & 223 & + & 7 \\
\hline Radix luteola typica & + & 5 & + & 2 \\
\hline Gyraulus ladacensis & + & 3 & + & 2 \\
\hline
\end{tabular}




\begin{tabular}{|l|l|l|l|l|}
\hline Indoplanorbis exustus & + & 2 & + & 3 \\
\hline Ariophanta interrupta & - & 0 & + & 5 \\
\hline Macrochlamys indica & - & 0 & + & 7 \\
\hline Total no. of fauna & 318 & & 41 & \\
\hline
\end{tabular}

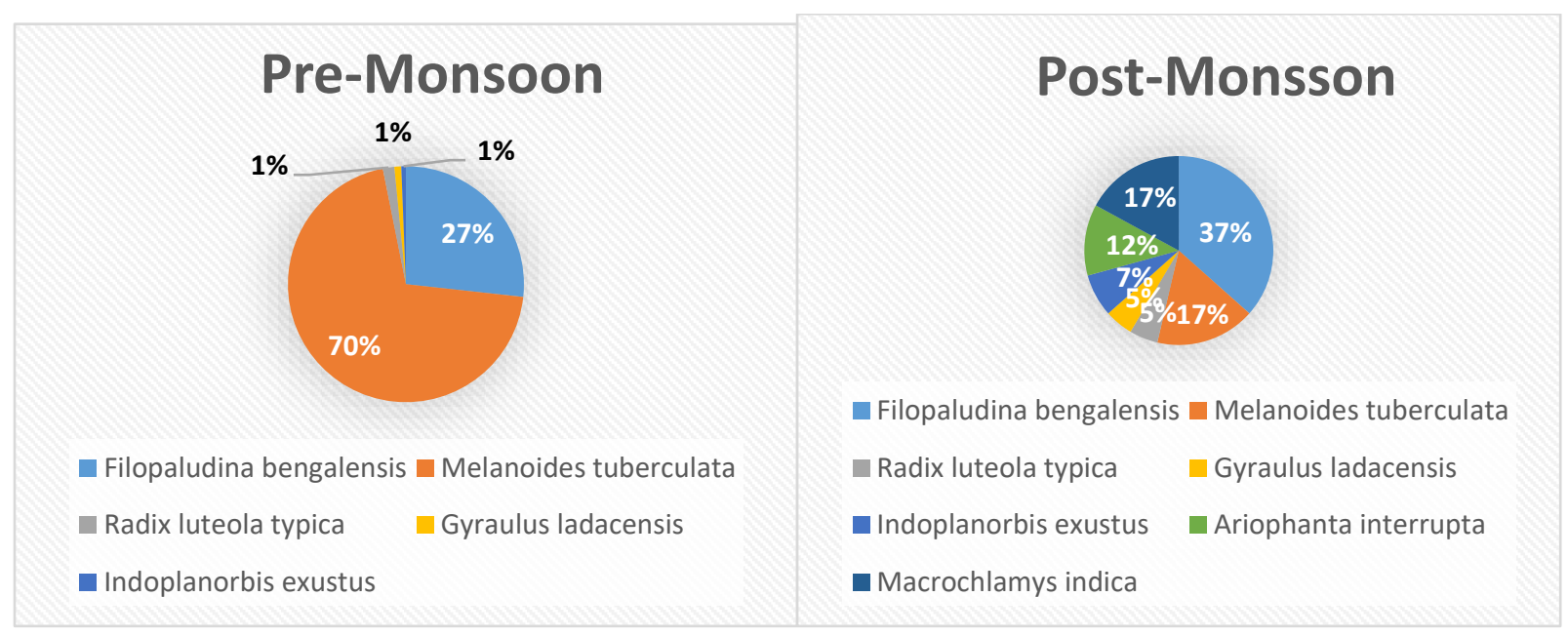

Figure 2: Percentage distribution of Mollusc species during Pre and Post Monsoon

Filopaludina bengalensis typica (Lamarck, 1822)

Figure 3

Shell dextral,conical in outline, medium sized, whorls 6 in number, plano-convex, color yellowish brown, bands dark spirally arranged, variable and irregular pattern of thick and thn bands; sutures impressed ; body whorl evenly convex, greatly swollen; penultimate whorl broader; spire pointed, height equal to body whorl; aperture sub circular with narrow black margin; umbilicus widely open; callus developed; ineer peristome clearly visible, distinct, thick rim like,not fused with body whorl, outer peristome thick.

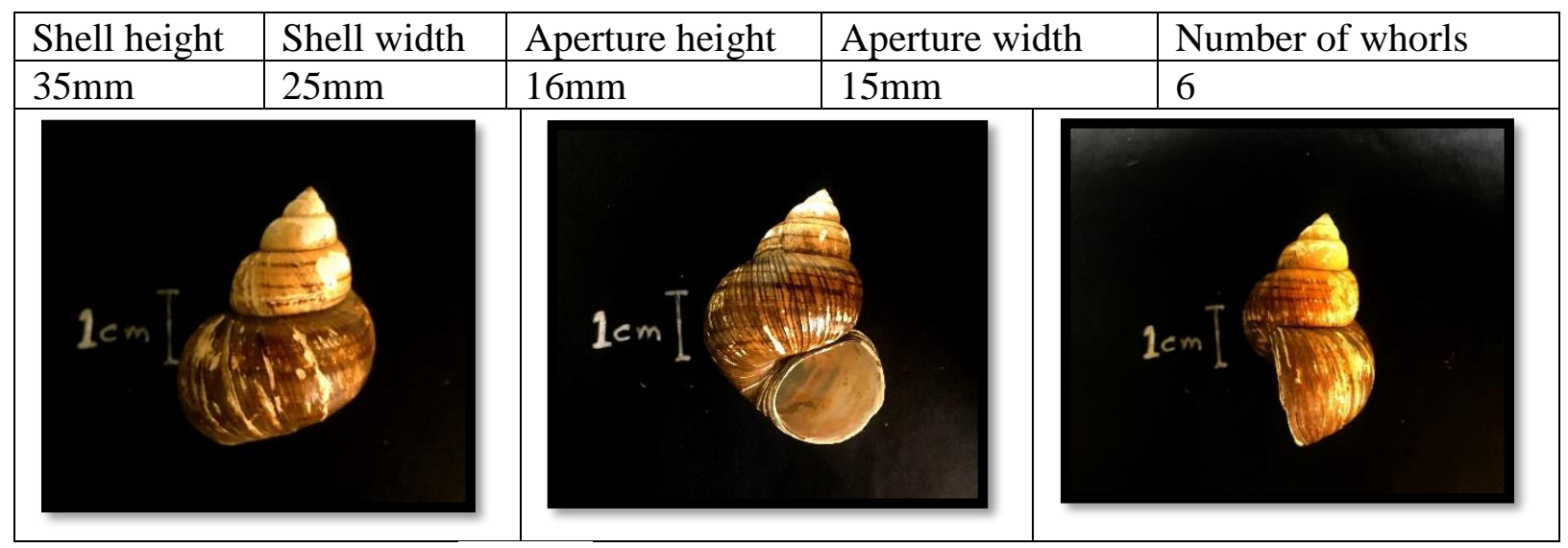

Figure 3: Filopaludina bengalensis typica 
Filopaludina bengalensis mandiensis (Lamarck, 1822)

Figure 4

Shell, dextral, more conical than typica, medium sized, whorls 6 in number, more convex than typica, color yellowish brown, alternative broad and narrow dark spiral bands, bands regular; sutures less impressed than typica; body whorl, evenly convex; penultimate whorl, less broader than typica; spire with pointed apex, height almost equal to body whorl; aperture ovoid; umbilicus narrowly open; callus well eveloped; innner peristome, not distinct, thin, fused with body whorl, outer peristome thin.

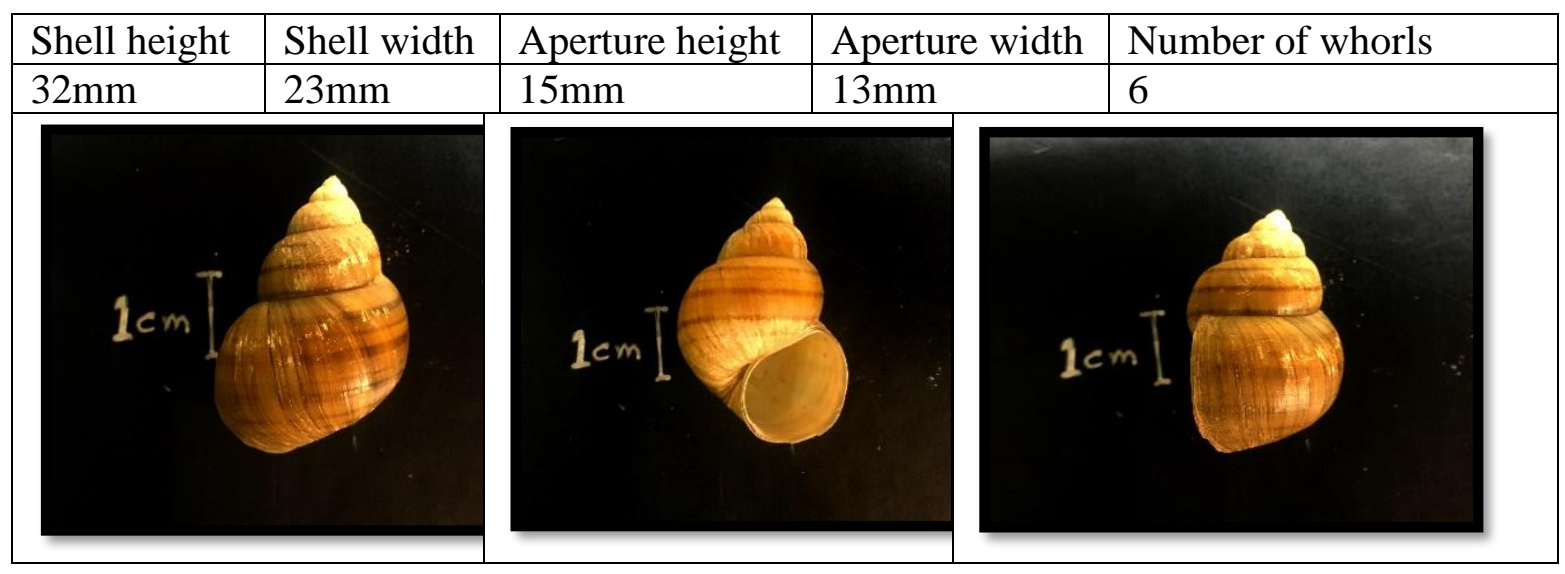

Figure 4: Filopaludina bengalensis mandiensis

Radix luteola typica (Lamarck, 1822)

Figure 5

Shell dextral, small, ovate, smooth, whorls 4 in numbers, length of suture at base of spire almost equal to height of spire, glossy, colour pale yellow with whitish bands; sutures transverse; body whorl inflated, broad at anterior end; spire conical, less pointed, placed little laterally to body whorl; aperture ovate, narrow, rounded below; umbilicus closed; callus very less developed, transleusent ;inner peristome fused with body whorl, outer peristome thin.

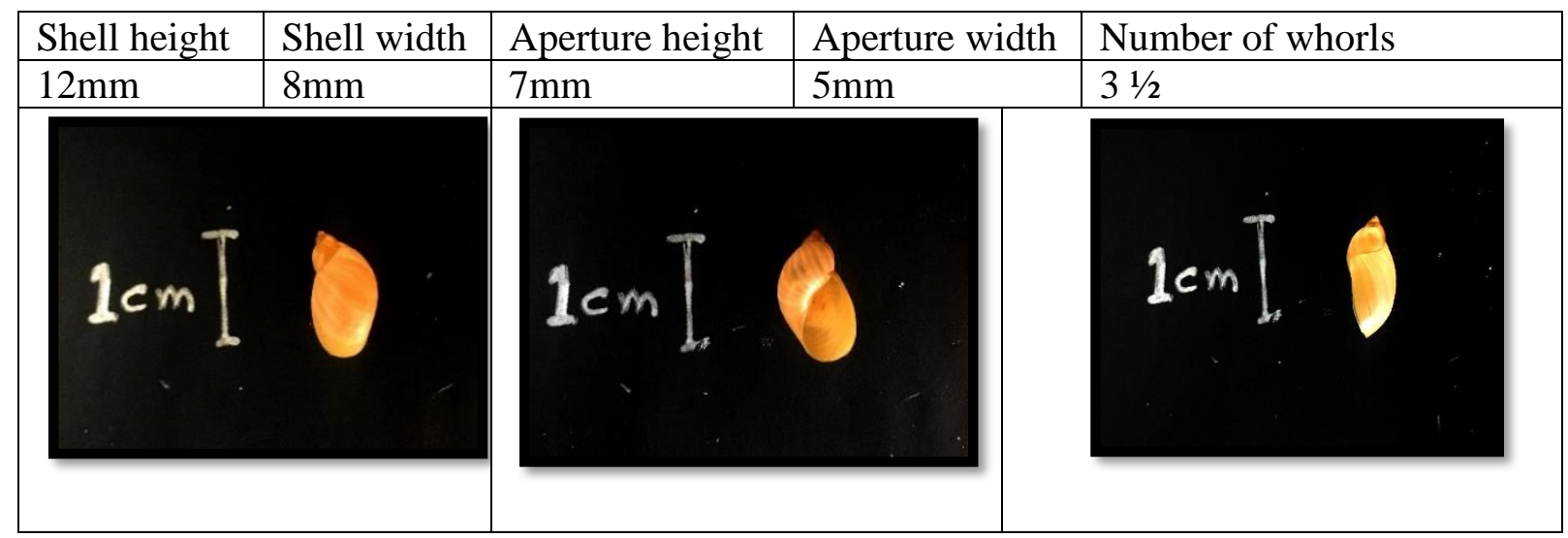

Figure 5: Radix luteola typica 
Melanoides tuberculata (Muller, 1774)

Figure 6

Shell dextral, turreted, neither very slender nor much elongated, whorls 9 in numbers, planoconvex, color dark brown, dark red brown dots and flames either irregularly distributed or longitudinally arranged on the shell surface, sculptured with vertical ribs and spiral striae, striae distinct and raised on upper whorls but flater on lower ones; sutures moderaltely impressed ;body whorl lightly convex; length of spire twice or little less than twice the length of body whorl; aperture pear shaped; umbilicus closed; callus developed, translucent ; inner peristome fused with body whorl, shows thickening on the seaprtion from body whorl, outer peristome thin.

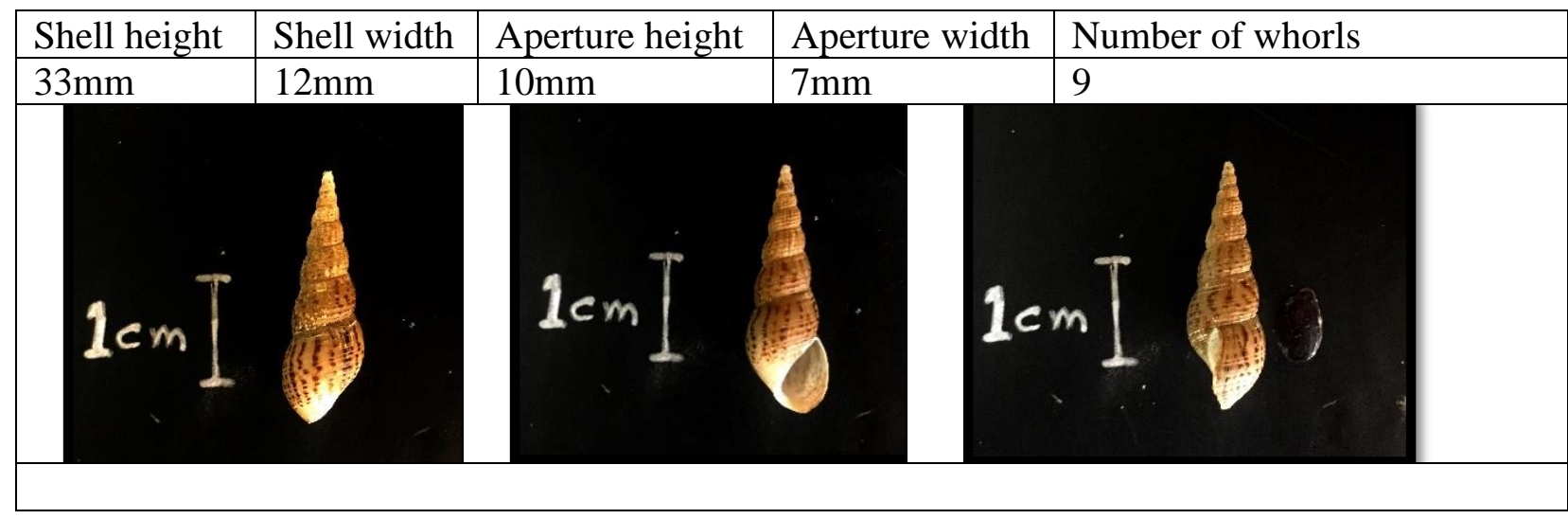

Figure 6: Melanoides tuberculata

Gyraulus ladacensis (Nevill, 1878)

Figure 7

Shell dextral, depressed, small, circular, convex laterally, almost flat above and below, whorls 3 in numbers, color yellowish white, without any coloured bands, striae oblique and longitudunal; body whorl rounded, non angulate, slightly compressed in the middle towards extremity; spire depressed; aperture little oblique, ovate, upper margin reaching a little beyond the columellar margin; umbilicus less deeply umblicate; callus less developed; both peristomes thin.

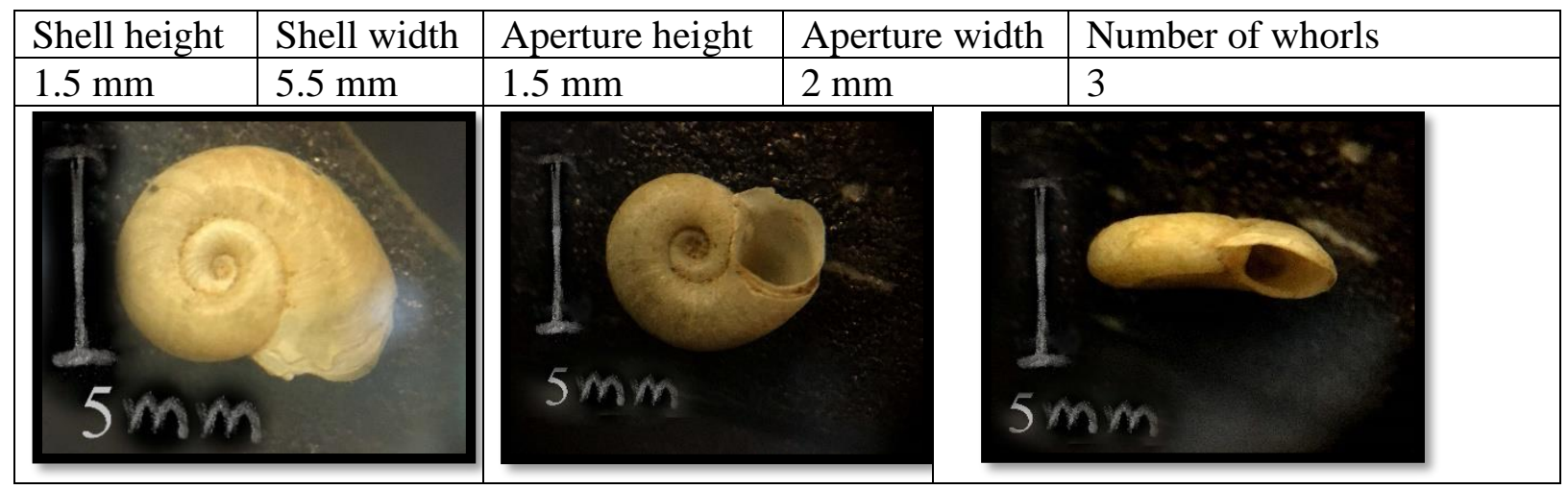

Figure 7: Gyraulus ladacensis 
Indoplanorbis exustus (Deshayes, 1834)

Figure 8

Shell sinistral, discoidal, flattened on both sides, whorls 3-4 in number, sutures deeply impressed, color creamish brown, without coloured bands; body whorl large and greatly expanded, surface transprially ridged; penultimate whorl very narrow; spire depressed; aperture ear shaped; umbilicus wide; callus developed; inner peristome fused with body whorl, outer peristome reflected outwards, rounded at periphery.

\begin{tabular}{|l|l|l|l|l|}
\hline $\begin{array}{l}\text { Shell } \\
\text { height }\end{array}$ & $\begin{array}{l}\text { Shell } \\
\text { width }\end{array}$ & Aperture height & Aperture width & Number of whorls \\
\hline $5 \mathrm{~mm}$ & $10 \mathrm{~mm}$ & $5.5 \mathrm{~mm}$ & $5 \mathrm{~mm}$ & $31 / 2$ \\
\hline & & & & \\
\hline
\end{tabular}

Figure 8: Indoplanorbis exustus

Ariophanta interrupta (Benson, 1834)

Figure 9

Shell sinistral, large, perforate, depressedly globose with blunt apex, outline bi-convex, whorls 4 in numbers, color brownish without coloured bands, surface sculptured, striae coarse, as oblique and decussating spiral lines; body whorl subangulate at the periphery and rounded below; spire little raised; aperture oblique, widely crescent shape; umbilicus deep and narrow; callus reflected at the perforation; peristome thick.

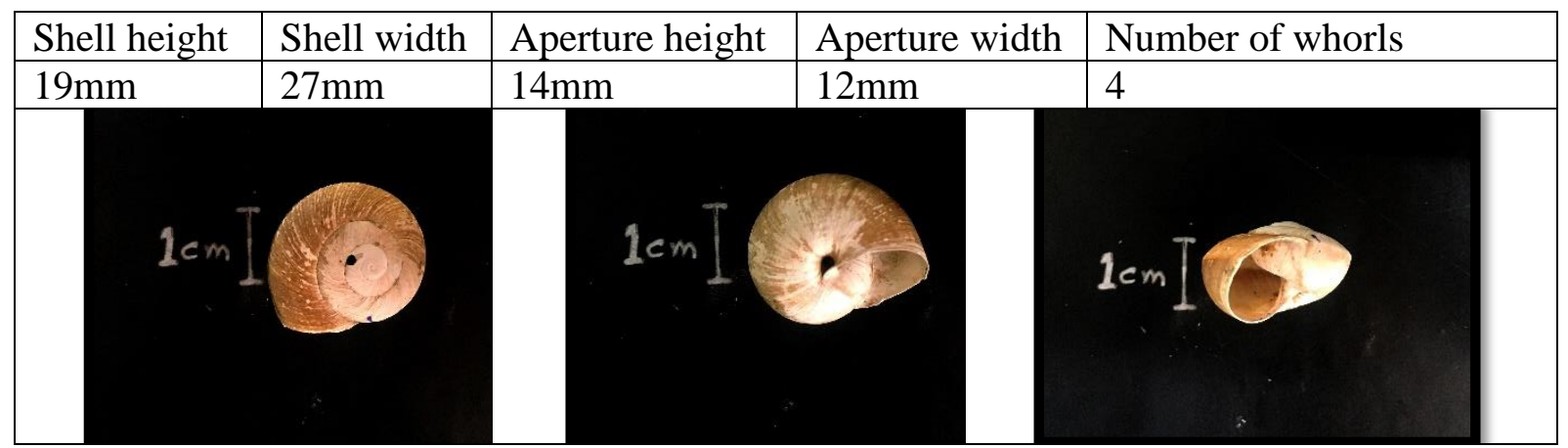

Figure 9: Ariophanta interrupta 
Macrochlamys indica (Godwin-Austen, 1833)

Figure 10

Shell dextral, moderate sized, thick, almost double broad than height, outline bi-convex, surface smooth and shining, whorls 5 in numbers, color pale brownish, upper surfce darker than under, striae radial and spiral; body whorl large, rounded at periphery; whorl gradually increasing in width; spire little raised; aperture lunate, sub vertical; columellar margin obliquely descending, slightly reflected above umbilicus, umblicus narrow and deep; callus well developed; inner peristome fused with body whorl, outer peristome thin.

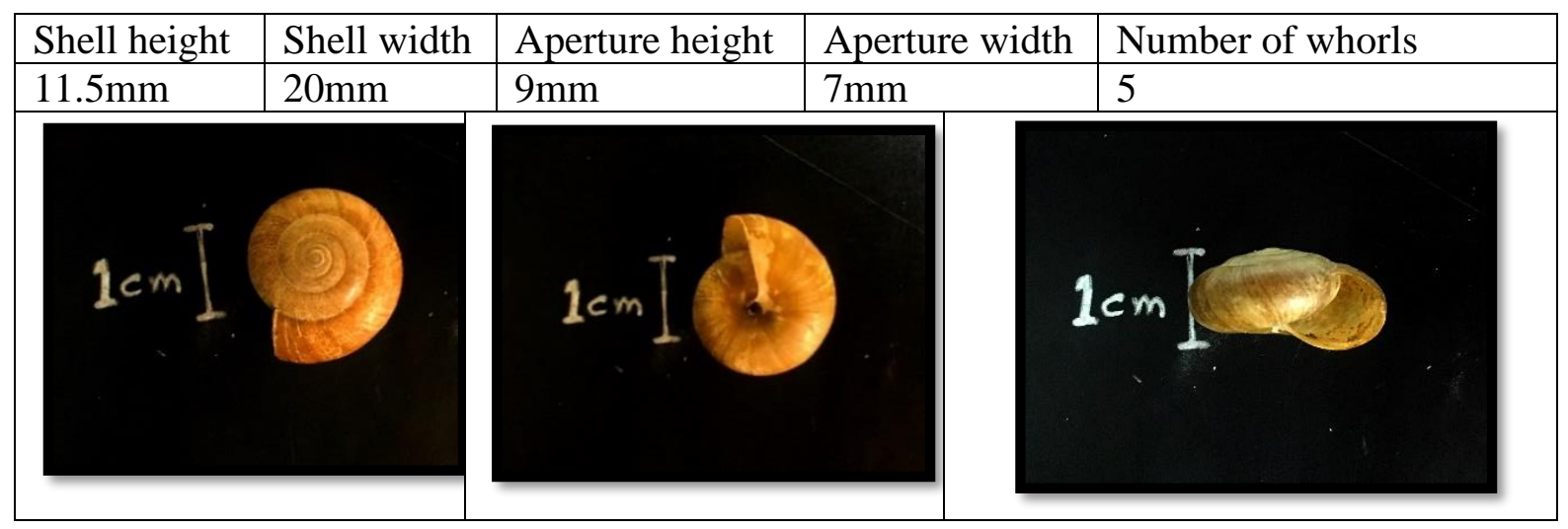

Figure 10: Macrochlamys indica

According to Shannon Weiner Index (H) and Simpson's Diversity Index (D) Post monsoon season is more diverse and different species are more evenly distributed. The values of Shannon Weiner Index $(\mathrm{H})$ for Pre and Post monsoon were 0.72 and 1.42 respectively. The higher value of $\mathrm{H}$ during Post monsoon season shows the greater diversity and evenness values calculated from $\mathrm{H}$ also showed that species are more evenly distributed in post monsoon season as compared to pre monsoon season. Simpson's Diversity Index (D) for Pre monsoon was 0.44 and for Post monsoon was 0.8 . This clearly indicates that post monsoon season favors more diversity of the mollusc fauna (Figure 2).

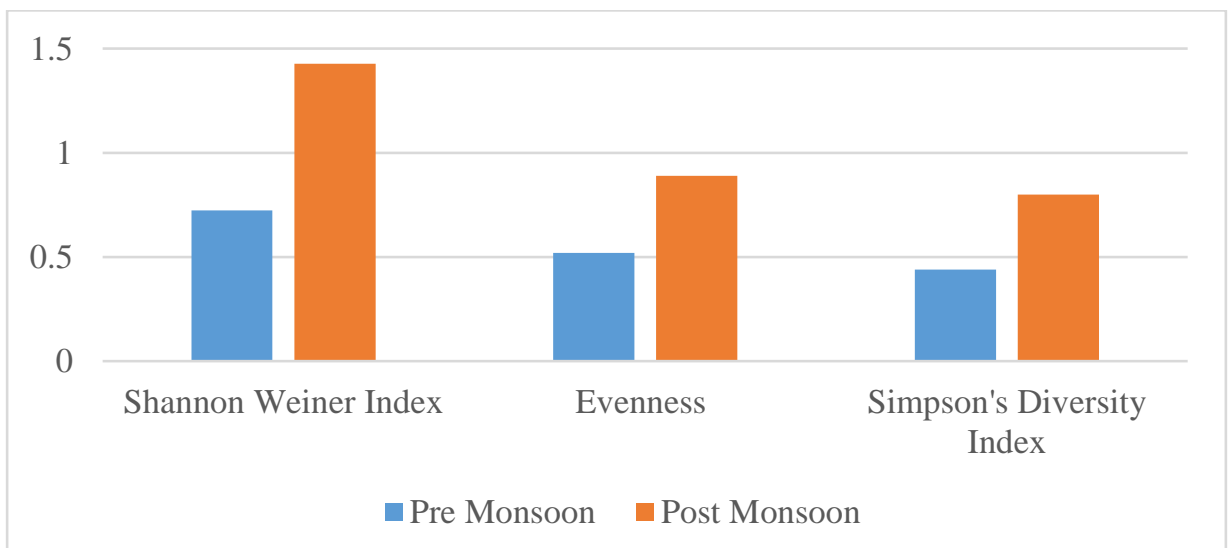

Figure 11: Seasonal variation in different biological indices of the molluscan fauna 


\section{Acknowledgement}

The authors are thankful to the Principal DAV College, Chandigarh for providing the infrastructure facilities to conduct the research work.

\section{References}

[1] Agrawal, H.P. (1975a): A CHECKLISTOF MOLLUSCS OF HIMACHAL PRADESH, INDIA. Part-I. 16(3): 38-41.

[2] Agrawal, H.P. (1975b): A CHECKLISTOF MOLLUSCS OF HIMACHAL PRADESH, INDIA. Part-II. 16(4): 59-60.

[3] Dey, A., 2007. HANDBOOK ON INDIAN FRESHWATER MOLLUSCS. AICOPTAX-Mollusca, Zoological Survey of India.

[4] Khade S.N. and Mane U.H. 2012. DIVERSITY OF EDIBLE BIVALVE AND GASTROPOD MOLLUSCS FROM RATNAGIRI, MAHARASHTRA. International Journal of Science \& Pharma Educational Research, 1 (8): 1-4.

[5] Kumar R.; Maansi and Wats M. (2018) ABUNDANCE AND ECOLOGICAL RELATIONSHIPS OF PHYSA ACUTA IN FRESHWATER BODIES OF CHANDIGARH (U.T), INDIA AND ITS SURROUNDING AREAS. Advance Research Journal of Multidisciplinary Discoveries.23.0,C-4 (2018) 21-26

[6] Kumar, A and Vyas, V. (2012). DIVERSITY OF MOLLUSCAN COMMUNITIES IN RIVER NARMADA, INDIA. Journ. Chem., Biol. Physical Sciences., 2(3): 1407-1412.

[7] Mitra, S. C and Day, A. 1992. LAND AND FRESHWATER MOLLUSCS; FAUNA OF WEST BENGAL. PT (9) MOLLUSCA. Zoological Survey of India, Kolkata. 1-268.

[8] Patil S.G. 2002. Mollusca. FAUNA OF EREAVIKULAM NATIONAL PARK. ZOOLOGICAL SURVEY OF INDIA. KOLKATA pp. 1-97.

[9] Patil S.G. and Talmale S.S. (2005). A CHECKLIST OF LAND AND FRESHWATER MOLLUSCA OF MAHARASHTRA STATE. Zoo's Print J. 20(6): 1912-1913.

[10] Ramakrishna and Dey, A. (2007). HANDBOOK ON INDIAN FRESHWATER MOLLUSCS. ZOOLOGICAL SURVEY OF INDIA.

[11] Ray, H. C. 1951. A NEW SPECIES OF THE GENUS MELANIA FROM THE CORAMENDEL COAST OF INDIA (MOLLUSCA, GASTROPODA; FAM; MALANIDAE). Rec. Indian. Mus., 50: 111-112.

[12] Ray, H. C. 1961. ON SOME NON MARINE MOLLUSK OF SOUTH INDIA. Treubia, 25: 273279.

[13] Roy, S and Gupta, A. 2010. MOLLUSCAN DIVERSITY IN RIVER BARAK AND ITS TRIBUTARIES, ASSAM, INDIA. Assam University Journal of Science and Technology: Biological and Environmental Sciences; 2010, 5(1), 109-11.

[14] Shannon, C. E., and Weaver, W., 1949. THE MATHEMATICAL THEORY OF COMMUNICATION. URBANA: University of Illinois Press.

[15] Sharma, B., Sharma, N. And Kumar, D. 2005. BIODIVERSITY OF FRESHWATER SNAIL FAUNA OF WESTERN UTTAR PRADESH. Uttar Pradesh J. Zool., 25(3) : 303-306.

[16] Sharma, K.K., Bangotra, K. And Saini, M., 2013. DIVERSITY AND DISTRIBUTION OF MOLLUSCA IN RELATION TO THE PHYSICO-CHEMICAL PROFILE OF GHOMANHASAN STREAM, JAMMU (JK). International Journal of Biodiversity and Conservation, 5(4), pp.240-249.

[17] Simpson EH. MEASUREMENT OF DIVERSITY. Nature. 1949.

[18] Subba Rao, N.V., 1989. HANDBOOK, FRESHWATER MOLLUSCS OF INDIA.

[19] Subba Rao, N.V. 1993. FRESH WATER MOLLUSCS OF INDIA 182-202 In.K.S.(Rao Ed). Recent Advances in Fresh Water Biology. 
[20] Subba Rao, N.V. and Mitra, S.C. 1979. ON LAND AND FRESHWATER MOLLUSCS OF PUNE DISTRICT, MAHARASHTRA. Rec. Zool. Surv. India, 75: 1-37.

[21] SUBBA RAO, N.V. AND MITRA, S.C. 1995. HIMALAYAN ECOSYSTEM SERIES: FAUNA OF WESTERN HIMALAYA-PART-1. Uttar Pradesh: 11-15.

[22] Surya Rao, K.V. and Mitra, S.C. 1997. FAUNA OF CONSERVATION AREA 9: FAUNA OF NANDA DEVI BIOSPHERE RESERVE: 25-28.

[23] Surya Rao, K.V., Mitra, S.C. and Maitra, S. 2002b. MOLLUSCAN FAUNA OF UJAINI.WETLAND ECOSYSTEM Series No. 3. Zool. Surv. India, pp. 133-142.

*Corresponding author.

E-mail address: meenuwats@ yahoo.co.in 